are slowed up, retarded, and finally changed." I have noticed it, over and over again, and I can show to-day, boys and girls -especially girls-whose instability of health is traceable to those miserable drugs.

Recognizing this perversion of cell growths and functions, and despairing of having my arguments accommodated with a hearing, I felt it incumbent on me to antagonize these effects, and it is my custom to seize every opportunity to show that the "drops" have done mischief. This is no difficult task, as these children are always complaining of ails and ills. I prescribe two drops of eucalyptol in milk three times a day, and it is good to be able to say that it promotes normal cell nutrition and antagonizes the disaffection of functions. It is my experience that this works admirably, not alone in affording temporary relief, but, moreover, in ensuring permaneut results. This is a matter of prophylaxis altogether valu bble and interesting, and one to be heartily commended. $T$ alm also using the eucalyptol for these youths out of my own clientele, and for others, who, I make no doubt, owe ill health or lessened vigor to the same cause. The results are uniform?y excellent.

It is not a pleasant matter to contemplate, but I subin:t that this "opiumism" of infancy is largely responsible for the mental perverts, the inebriety, and the lack of mental, physical, and moral stamina, so largely in evidence.

Sincerely yours,

GTFfard Knox, M.D.

\section{The New York Pathological Institute.}

HaRTFord, Conn, May 21, 1900.

To the Editor:-The ways of politicians in New York are always mysterious and startling. The unknown is always happening, particularly to institutions that are not well founded in public opinion. In the early sixties an inebriate asylum was founded at Binghamton. Later, the state took charge of it, and after a varied career under "boss rule" it was finally turned into an insane asylum. A little farther on in the history the reformatory at Elmira was founded and conducted on most advanced lines. Then the same old battle concentrated about it and tremendous efforts were made to destroy it, and change it to some other work. Fortunately, this failed. The epileptic asylum has been the center of the controversy, and were it not for very wise management a political battle would have begun to change and break it up before this.

Now comes similar storm and effort to break up the pathologic institute. For reasons unknown and inconceivable, the superintendents of the state hospitals and the politicians are in great doubt as to the value of the work there. They urge abolishment of the work or changing it in some unknown way to the interest of the tax-payers, etc. This institute, inaugurated for the purpose of utilizing and studying the mass of material gathered, is practically a laboratory for the higher study of psychopathy, and is the first one organized in this country. Already its reports give promise of researches of the most practical character on the causes and condition of in sanity. The five volumes of papers bearing on these higher questions are the foundations of an entirely new field of psychiatry, and in the work done there is more practical advance and more suggestive study than in the asylum literature of half a century. This institute is designed to make exhaustive studies, both microscopically and statistically, of all the phases of insanity and the various conditions which re. sult in brain defects. This is done by trained experts who have nothing but the facts to ascertain, and have no other duties than those of scientific study. The asylum pathologists are supposed to send specimens of morbid anatomy, histories of disputed cases, and psychologic facts to this institute for final study. Matters which are not clear to the busy physicians on the staffs of these crowded hospitals are sent to this institute for study at leisure. There is in this an almost infinite field of most practical scientific work of the greatest value to every citizen of the state as well as to those of other states.

There is something startling in the adverse feeling of the superintendents of the various asylums to this work, and it is incomprehensible why they should not be its warmest ad- mirers and seek in every way to continue a work which makes their own more and more accurate and scientific. It has been a matter of surprise to visitors at the older insane asylums of the country to find such an enormous accumulation of clinical histories of patients piled away in rooms as so much lumber. The staff has no time and perhaps little ability to study or analyze these records and make practical use of them. An institute could utilize these facts and show their practical meaning as no asylum could. There must be some central head with time and skill to study facts of this character. New York State has taken the lead with the warmest endorsement of every scientific man, and the present effort to break up the institute or narrow and change its work would be a calamity to science. We can not believe that the friends of psychopathy will permit such a change. The very absence of central scientific laboratory work has much to do with the confusion and ignorance of many phases of practical medicine. The whole trend of modern medicine is to centralize and specialize the study of all its various phases so that it can become more and more a science. The threatened destruction of the New York Pathological Institute is one of the perils which we hope may be avoided by wiser counsel and broader views.

T. D. Crothers, M.D.

\section{Deaths and Dbituaries.}

EDward Oram Shakespeare, M.D., Philadelphia, died suddenly, June 1, from chronic cardiac trouble. He was born of distinguished lineage in New Castle County, Delaware, May 19, 1846. He was graduated from Dickinson College in 1867, and from the Medical Department of the University of Pennsylvania two years later. He began the practice of his profession at Dover, Del., but in 1874 removed to Philadelphia, where later he was appointed lecturer on operative ophthalmic surgery in the University of Pennsylvania. He was, in 1885 , sent as the representative of the Federal Government to Spain and other European countries in which cholera was prevalent, to investigate the cause, prevention, and cure of that disease. He spent seceral months abroad in the study of the subject, and made a report to Congress. During the war with Spain he was appointed a brigade surgeon, with the rank of major of volunteers, and at the time of his death he was acting as a member of the commission attached to the office of the Surgeon-General at Washington to investigate the causes of typhoid fever in the United States Army. He was a member of many scientific societies, including the Delaware Medical Society, the Northern Medical Society, the Pathological Society of Philadelphia, and the Philadelphia County Medical Society. He contributed to The American Journal of Medical Sciences for January, 1870, a paper on "A New Ophthalmoscope and Ophthalmometer, Devised for Clinical Use and for Physiolog. ical and Therapeutical Investigation on Men and Animals," which he had invented.

James T. WhitTaker, M.D., professor of theory and practice in the Ohio Medical College, died June 5 , at his home in Cincinnati, of recurrent intestinal carcinoma. He graduated from Oxford University in 1863, and served for a time in the Union Army as a private. After this service he resumed the study of medicine, but again left college to accept an assistant surgeonship in the Navy, serving on the Cumberland. At the close of the war he entered the medical department of the University of Pennsylvania, where he graduated in 1866 . He made two trips to Europe, enjoying the advantage of personal instruction from Dr. Robert Koch. He has served on the medical staft of the Cincinnati Hospital and at the time of his death occupied a similar position at the Good Samaritan.

W. H. I. O'MALley, M.D., assistant surgeon of the Cal. Twelfth Inf., died in San Francisco. May 24, aged 38 years. He was graduated from the University of California in the department of liberal arts and medicine. In 1898, he became a. contract surgeon and was sent to Honolulu, where he remained until he was transferred to the Philippines. He was injured in December and again in February, and returned to San Francisco on the transport Sherman, April 25.

L. J. Jones, M.D., Wichita, Kan., died in Galena, Kan., 